\title{
TITLE:
}

\section{Activation of JNK in the Inner Ear Following Impulse Noise Exposure( Abstract_要旨 )}

\section{$\operatorname{AUTHOR}(\mathrm{S})$ :}

Murai, Norihiko

\section{CITATION:}

Murai, Norihiko. Activation of JNK in the Inner Ear Following Impulse Noise Exposure. 京都 大学, 2008, 博士(医学)

ISSUE DATE:

2008-07-23

URL:

http://hdl.handle.net/2433/124329

RIGHT: 


\section{\begin{tabular}{|l|l|l}
\hline 京都大学 博士（医学） & 氏 名 & 村井 紀彦 \\
\hline
\end{tabular} \\ 論文題目 \\ Activation of JNK in the Inner Ear Following Impulse Noise Exposure \\ (衝撃性音響曝露後の内耳における JNK 活性化)}

\section{(論文内容の要旨)}

音響外傷による感音性難聴は難治な疾患であり、新しい治療法の開発がまたれる。音響外傷は その刺激の強度に応じて、内耳に機械的および生化学的障害を与えるが、治療法の開発のひとつの 標的は細胞死情報伝達機構の阻害である。細胞へのストレスによって活性化されるc-Jun N

terminal kinase(JNK)は内耳においても作動していることが知られている。JNKによる細胞情報 伝達は細胞の生存とアポトーシスの両方に関与することが知られている。騒音曝露は蝸牛で細胞死 を誘発することも知られている。JNK情報伝達は、他の内耳障害モデルであるアミノ配糖体耳毒性 モデルにおいて活性化され、その情報伝達の阻害が内耳障害の軽減をもたらすことが報告されてい る。しかし一方シスプラチンによる内耶障害モデルにおいてはJNK情報伝達の阻害は逆の結果をも たらすことが報告されている。個々の内耳障害モデルにおいてJNKはどのような情報伝達を担って いるのか、さらに検討寸る必要がある。今回、すでによく確立された内耳音響外傷モデルである、 衝撃性音響外傷モデルを用いて、衝撃性音響曝露後 24 時間以内の早期の変化に焦点をおき、内耳 における細胞死とJNKリン酸化の関倸を検討した。成体白色ラットが麻酔され、一回の衝撃性音響 $(194 \mathrm{kPa})$ に曝露された。3時間後または24時間後に内耳組織が採取された。

脱灰パラフィン包埋標本切片が作製され、リン酸化JNKの標識の探索のためにリン酸化JNKに文 寸る免疫組織化学染色が行われた。また、断片化DNAの存在の標識としてTUNEL法による評価が 行われた。HE標本により、蝸牛の各細部位において、光学顕微鏡学的形態はよく保たれているこ とが確認された。リン酸化JNK標識細胞は曝露3時間後においては、コルチ器外有毛細胞、ラセン 勒帯、ラセン神経節で観察され、曝露24時間後では、コルチ器外有毛細胞、ラセン神経節で観察さ れた。TUNEL標識細胞は曝露3時間後には観察されなかった。曝露24時間後ではコルチ器、ラセ ン板縁、血管条、ラセン鞋帯において観察された。部位別にみると、ラセン板縁と血管条において は、衝撃性音響曝露24時間後に陽性のTUNEL標識が観察されたが、これらの部位ではJNK活性化 は3時間後にも24時間後にも観察されなかった。コルチ器とラセン勒帯においては、曝露3時間後に リン酸化JNKの標識が確認された後に、曝露24時間後にTUNEL標識細胞が観察された。また、ラ セン神経節においては3時間後、24時間後いずれにおいてもリン酸化JNK標識が観察されたが、

TUNEL標識細胞はこの時間枠内では観察されなかった。コルチ器とラセン勒帯においては、JNK の活性化が細胞死に関連することが示唆されたが、その他の部位ではJNK活性化とTUNEL標識の 関連は観察されなかった。これらの結果から、衝撃性音響曝露後の内耳におけるJNK活性化はコル チ器だけでなく、ラセン勒帯においても細胞死に関連していること、またJNKに依存しない情報伝 達によって細胞死に至る細胞もあることが示唆された。この研究は音響外傷における内耳障害にお いてJNKを含めた多様な細胞死情報伝達経路が作動することを示し、細胞死防御による内耳障害治 療方法の開発に寄与寸るものである。
（論文審查の結果の要旨）

音響外傷治療の標的として、ストレスで活性化されるc-Jun N-terminal kinase(JNK)の細胞死 一の関与を解明するため、申請者らは衝擊性音響期暴露後 24 時間以内での内耳細胞死とJNKリン酸化 を検討した。麻酔下に音響曝露された白色ラットから 3 時間後または24時問後に内耳組織を採取し、 リン酸化JNKの免疫組織化学染色、断片化DNA標識のTUNEL法を行った。感覚上皮であるコル チ器と、内リン八゙振動を直接受ける基底板を支持するラセン勒帯においては、曝露3時間後にリン 酸化JNK標識が、曝露24時間後にTUNEL標識細胞が観察された。コルチ器上の蓋膜を把持するラ セン板縁と、蝸牛側壁にあって内リンパ液生成に関与寸る血管条では、24時間後にTUNEL標識か 観察されたが、JNK標識は観察されなかった。有毛細胞に接続する神経節のラセン神経節では3時 間後、24時問後いずれでもリン酸化JNK標識が観察されたが、TUNEL標識細胞は観察されなかっ た。コルチ器だけでなく、内リンパ電位維持機能を担うラセン勒帯においてもJNKが細胞死に関連 すること、また蝸牛恒常性維持にとって重要な血管条においてはJNKに依存しない細胞死も関与寸 ることが示唆された。以上の研究は音響外傷性内耳障害の細胞死情報機構の解明に貢献し、内耳障 害治療方法の開発に寄与寸るところが多い。

したがって、本論文は博士(医学)の学位論文として価值あるものと認める。

なお、本学位授与申請者は、平成 20 年 6 月 24 日実施の論文内容とそれに関連した研究分野並びに学 識確認のための試問を受け、合格と認められたものである。 